\title{
The quality of carbon management accounting reporting as a financial barrier to clean development mechanism projects development
}

\author{
ANDRÉ LUIZ BUFONI ${ }^{1}$ \\ Aracéli Cristina de SoUsa Ferreira' \\ LUCIANO BASTO OLIVEIRA ${ }^{1}$ \\ ${ }^{1}$ UNIVERSIDADE FEDERAL DO RIO DE JANEIRO, RIO DE JANEIRO - RJ, BRAZIL
}

\begin{abstract}
Recent works reveal that financial attractiveness is a severe barrier to the GHG emissions reduction projects in developing countries. Because of price collapse of the carbon market since 2013, the importance of projects budgeting and forecast has risen. This article aims to investigate the financial information and disclosure quality of 432 projects of the waste management sector using UNFCCC's Clean Development Mechanism as a Kyoto Protocol Instrument. The research used the qualitative content analysis methodology supported by NVivo ${ }^{\circledR}$ software. The results indicate that the lack of reporting standards and the poor-quality information lead to significant reduction of the audits utility, due to the uniformity, consistency, trustworthiness, and predictive and feedback qualitative characteristics of data presented. The real situation and the performance of initiatives are hardly known, but according to data activities, projects are continually compromised. However, the study concludes that the need for quality is a great professional and research field to explore.
\end{abstract}

Keywords: Accountability. CDM. Renewable Energy. Kyoto.

A qualidade da evidenciação da informação financeira gerencial como uma barreira para o desenvolvimento de projetos do mecanismo de desenvolvimento limpo

\begin{abstract}
Resumo
Trabalhos recentes revelam que uma barreira severa aos projetos de redução de emissões de gases de efeito estufa em países em desenvolvimento é a atratividade financeira. Devido ao colapso dos preços do mercado de carbono desde 2013, a importância do orçamento e previsão de projetos aumentou. Assim, este artigo tem como objetivo investigar a qualidade da informação e da divulgação financeira em 432 projetos do setor de gestão de resíduos sob o Mecanismo de Desenvolvimento Limpo da UNFCCC como um Instrumento do Protocolo de Quioto. A pesquisa usa a metodologia qualitativa de análise de conteúdo suportada pelo software NVivo ${ }^{\circledR}$. Os resultados indicam que a falta de padrões de relatórios e a má qualidade da informação levam a uma redução significativa de sua utilidade, devido à falta de uniformidade, consistência, confiabilidade e características qualitativas de previsão e feedback dos dados apresentados. De fato, a situação real e o desempenho das iniciativas são pouco conhecidos, mas, de acordo com os dados, a continuidade dos projetos está gravemente comprometida. No entanto, por outro lado, o estudo conclui que as demandas por qualidade são um grande campo profissional e de pesquisa a serem explorados.
\end{abstract}

Palavras-chave: Accountability. MDL. Energia Renovável. Quioto.

La Calidad de la evidenciación de la información financiera gerencial como una barrera para el desarrollo de proyectos del mecanismo de desarrollo limpio

\section{Resumen}

Los trabajos recientes revelan que el atractivo financiero es una barrera severa a los proyectos de mitigación de emisiones de gases de efecto invernadero en países en desarrollo. Debido al colapso de los precios del mercado de carbono desde 2013, la importancia del presupuesto y previsión de proyectos aumentó. Así, este artículo tiene como objetivo investigar la calidad de la información y de la divulgación financiera en 432 proyectos del sector de gestión de residuos bajo el Mecanismo de Desarrollo Limpio de la UNFCCC como un instrumento del Protocolo de Kioto. La investigación usa la metodología cualitativa de análisis de contenido sostenida por el software NVivo ${ }^{\circledR}$. Los resultados indican que la falta de estándares de informes y la mala calidad de la información conducen a una reducción significativa de su utilidad, debido a la falta de uniformidad, consistencia, confiabilidad y características cualitativas de previsión y feedback de los datos presentados. De hecho, la situación real y el desempeño de las iniciativas son poco conocidos, pero, de acuerdo con los datos, la continuidad de los proyectos está gravemente comprometida. No obstante, por otro lado, el estudio concluye que las demandas de calidad son un gran campo profesional y de investigación por explorar.

Palabras clave: Accountability. MDL. Energía renovable. Kioto. 


\section{INTRODUCTION}

Waste management will still be a relevant and continuing global issue for a long time because of our unsustainable consumption patterns, the shortening product life cycles, the recycling limits, and the modest prevention and re-use rates (BARTL, 2011; 2014)recycling processes require energy and will generate side streams (i.e. waste. Although "the effective technologies required to 'solve' the waste issues are largely already available, and have been much written about" (WILSON and VELIS, 2015), recent studies indicate that the developing countries face several constraints to implementing those technologies (BUFONI, OLIVEIRA and ROSA, 2016; GODFREY, SCOTT and TROIS, 2013; GUERRERO, MAAS and HOGLAND, 2013; SIMÕES and MARQUES, 2012; YOON and SIM, 2015)

While the barriers to projects development in those countries may widely vary depending on local conditions, the official and agencies manuals, and bank guidelines, as well as the global reports point the financial constraints as one of the greatest obstacle precluding the waste management system performance (COP 10, 2011; EUROPEAN ENVIRONMENT AGENCY, 2013; HOORNWEG and BHADA-TATA, 2012; OECD, 2015; UNEP, 2015; UNFCCC, 2012; USEPA, 2014).

The most recent relevant example, the United Nations Environment Programme - UNEP (2015) report entitled Global Waste Management Outlook (GWMO), dedicates fifty-seven pages to describe models for the financing solutions and economic instruments design. Moreover, after considering the importance of transforming raw data into useful information for performance indicators construction, and that it can, then, be used to make wise decisions, the first conclusion is (UNEP, 2015, p. 204):

Understanding both the financial and economic costs of waste management remains a global challenge. Sustainable waste management solutions need a reliable economic evidence base, and much more work needs to be done, both globally and in particular in developing countries (UNEP, 2015, p. 204).

Because of the "reliable economic base" barrier in developing countries, the research question that drives the objective of this work is: How are the statements and what is the quality of the financial information presented to register a project as a Clean Development Mechanism at UNFCCC? Thus, this paper aims to investigate the financial assumptions and disclosure quality at 432 projects design documents of the waste management sector (13) under UNFCCC's Clean Development Mechanism as a Kyoto Protocol instrument.

We choose UNFCCC's database and Waste Management Sector to proceed the qualitative content analysis, because waste management research pays little attention to financial issues, and does not operate in a broad, systemic view (ALLESCH and BRUNNER, 2014; SINGH, LAURENTI, SINHA et al., 2014), and because worldwide industry databases, information systems, and inventories, which could significantly support decision makers, are also very scarce (BUFONI, OLIVEIRA and ROSA, 2016; BUFONI, OLIVEIRA and ROSA, 2015; INANC, IDRIS, TERAZONO et al., 2004).

During the first Kyoto Protocol commitment period (CP1, 2008-2012), developing countries (DCs) implemented almost one thousand (949) waste management projects. Europe Union Emissions Trade System (AAUs) can buy and trade the resultant certified emission reductions (CERs) for the abatement of 1.6 billion tons of $\mathrm{CO}_{2}$ between 2008 and 2020. This quantity represents half of the emissions reduction in the trade system during that period (EUROPEAN COMMISSION, 2015).

For Kyoto's second commitment period (CP2, 2013-2020) the CER prices collapsed, and by the end of 2013, the number of proposed transactions reached its lowest value since 2008 (ITL, 2013). Therefore, the future registration of waste management projects as CDMs is uncertain, projects will postpone improvements to existing technology, and financial analyses without CER revenues and quality reporting increase in importance.

Next section presents the methodology with strategy, unit in the analysis, research procedures, and sample description. The third part presents the findings of the data analysis that we will bring to the discussion at a fourth part, in pair with a brief social and environmental accounting (SEA) literature review. The last section draws some conclusions and some future research recommendations. 


\section{MATERIAL AND METHODS}

This paper uses the qualitative strategy of computer-assisted document content analysis (CAQCA). The concept of CAQCA is the interpretation of variations expressed as categories and themes at various levels of abstraction (EGBERG THYME, WIBERG, LUNDMAN et al., 2013). The evidence convergence via the identification of differences and similarities of content allows "greater confidence in the trustworthiness (credibility) of the findings" (BOWEN, 2009; EGBERG THYME, WIBERG, LUNDMAN et al., 2013).

Furthermore, the approach is relevant for the study of impression management strategies used in corporate communications (TALBOT and BOIRAL, 2015). Bowen (2009) highlights five additional functions of documents in a CAQCA: (1) documents provide background and context, (2) additional questions to be asked, (3) supplementary data, (4) a means of tracking change and development, and (5) verification of findings can provide the research context.

In this study, we use the qualitative data analysis software (QDAS) NVivo 10 to increase the probability of finding relevance mainly due to credibility, verifiability, transferability, and auditability of results (DAVIDSON and JACOBS, 2008; MACKENSEN and WILLE, 1999; SMYTH, 2006). The QDAS also permits the management of large data samples, has search and coding engines, statistical tools for hypotheses tests and conceptualization.

In total, we verified 432 large waste management projects from 55 countries, extracted from the Project Search on the CDM site (UNFCCC, 2015c) using the following criteria: "Waste handling and disposal (13)" for sectoral scope, "Large" for scale and "Registered" for status. We classified the data by the four digit reference number. For example, (0008) refers to the Brazil NovaGerar Landfill Gas to Energy Project. The UNFCCC has specific methodologies for each project type, repeated here: 253 landfills (ACM0001), 60 manure (ACM0010), 51 wastewater (ACM0014), 39 incinerators, 23 composting, one gasification, two sewage sludge processes and 3 refused derived fuel (ACM0022). Appendix A summarizes the sample in Table A.1.

The unit in analysis is the projects section submitted to attend the "Guidelines on the assessment of investment analysis" (UNFCCC, 2015a), which are available on the UNFCCC website. The Investment Analysis step (2 or 3 ) is divided into the following steps: (a) determine appropriate analysis method; (b) apply the analysis method; (c) calculation and comparison of financial indicators; and (d) sensitivity analysis. If the CDM project activity generates no financial or economic benefits beyond CDM related income, then designers apply the simple cost analysis (Option I). Otherwise, they use the investment comparison analysis (Option II) or the benchmark analysis (Option III). Steps (c) and (d) are only available when a project uses Option II or III. How the investment and the financial analysis were presented separately from the other sections of the documents, the authors decided to read the entire 432 referred parts. The task took four months.

One recurring issue in qualitative research is the concern with internal validity. The methodology authors recommend the employment of two techniques to strengthen the research results credibility: (a) member checking, where the collected data is 'played back' recursively, and (b) researcher-theory-data-method triangulation (CHO, 2006; CHOWDHURY, 2014; DÖÖS and WILHELMSON, 2012; KRIPPENDORFF, 2004; YIN, 2013). Authors revised the data using both techniques several times: at literature review, project analysis, doctoral seminars, familiarity study (a qualitative version of a pilot study) (BUFONI, OLIVEIRA and ROSA, 2015).

\section{RESULTS}

\section{Disclosure of financial forecast}

The projects' financial disclosure (budget and forecast) typically improves with time. This improvement in part is due to revisions of the UNFCCC methodologies adding more 'guidelines' that foster information quality uniformity (UNFCCC, 2011). However, it is clear that there is no published model or template for the submission of reports, which in many cases makes 
the financial data confusing, incomplete and biased. Indeed, the guidelines document has only five pages that are dedicated almost entirely to discount rates and benchmarks issues.

As a result, forty projects, mainly classified as landfill gas flare, compost, and wastewater, present no financial information (opacity). The absence of information on projects that adopted the Avoided Wastewater and On-site Energy Methodology (AM0022) affirm that "Since only one most plausible baseline option can be identified, this investment analysis is not applicable" $(2076,2110,2138,2144,2180$ and 7018).

Fortunately, the growth of project's complexity or its benchmark, and the addition of other sources of income beyond the sale of certificates makes simple cost analysis (Option I) (51 projects) inappropriate. Even so, in many projects the message is simply a brief, "This step is skipped" (e.g., 2374 and 5194), or "There are not sufficient data available for a regular investment analysis" (5460). In other cases, the project declared the information to be "confidential," unavailable (indicated by a dash) (8126), blank (8242) or "not chosen and therefore not discussed" $(7658,8181)$. In at least 20 other cases, the NPV and IRR indicators are declared without the values or assumptions they use to support their calculations (e.g., 5842). Again, old compost and wastewater initiatives were more likely to have this problem (0169, 1176 and 2427).

Somewhere in time (2006), the UNFCCC recommended the presentation of an additional worksheet with the financial data. We analyzed it also. The format and extension of the financial statements significantly vary, except when the projects come from the same consultant (e.g., 39 AgCert AWMS projects), country and industry (China incinerators), which is fairly usual. In part, this disclosure 'standardization' favors the uniformity but significantly distorts the statistics, because of its unique format.

Besides the language errors that can be significant (e.g., 7777), currency variety is another difficulty, because there are 25 different currencies in the reports with no translation, exchange rate, or any assumption indicated. This issue reduces the comparability since it makes the statement not easily or accurately translatable $(5364,5692)$. Also, the listed exchange rates are not always accurate for the period (e.g., the year of 2006: 3 BRL $=1$ USD or 10 CNY = 1 EUR). The use of " $10^{4}$ notation" rather the typical listings of thousands or millions add confusion to the projects. In the case of Morocco (5434), the units are operational (dose-response style), not the national currency.

\section{Financial assumptions}

The objective of the CDM investment analysis is to assess the attractiveness and economic feasibility of the carbon reduction project with and without the tradable CERs. The Executive Board guidelines recommend assets to be registered using the "local accounting fair value." Calculations would include book value and the reasonable expectation of potential profit or loss on assets realization. Not to apply the residual value would imply capital expenditure (CAPEX) payback.

How the attractiveness indicators are financial (NPV and IRR), CAPEX should be in cash flow, and depreciation and other noncash expenses should be added back to net profits, in a usual EBITDA calculation style. While 153 projects include net present value (NPV) calculations, with only one positive occurrence (4598), 213 projects present the internal rate of return (IRR), of which 162 are positive. No IRRs accomplish the benchmark. Some projects (42) include both indicators.

In general, perceived and declared financial assumptions have some intentional shortcomings and pitfalls. The behavior is because it is in the essence of a CDM to be unattractive without certified emissions revenue (1123). In words, registration must alleviate the financial barriers (UNFCCC, 2012) with the carbon credits. Thus, the information might not be qualitative neutral, or unbiased, explaining why out of 432 projects, only one project declared itself attractive (BUFONI, OLIVEIRA and ROSA, 2015). In fact, a recent study discards the results of the financial analyses of the PDDs to suggest the barriers in the sector (BUFONI, OLIVEIRA and ROSA, 2016).

Per example, the revenue of the CERs is many times declared. The expected price or 'rights to sell' contract are always the same from US\$6.00 to US\$20.00 (4061) during the entire registration period or lifetime (usually 7-21 years), but the mode is US\$10 and 8.0€. No significant difference in value was found between countries, project types or over time. In very rare cases, the negotiable security prices were lower after Kyoto first period than initially estimated (e.g., 20\% or 50\%) (6797). Some projects include only the expected CER income total $(6780,6945,7041$ and 8064), and in at least four cases, CER income is not mentioned at all $(6867,7733,8593$ and 8751$)$. In fact, some projects estimated $18 €$ per metric ton of $\mathrm{CO}_{2}$ eq in 2012 
(9303), and US\$20.80 (9686) in 2013 (Figure 1). These 'estimated' values are completely unrealistic for planning purposes (POINT CARBON, 2012). At the end of 2012, the exchange price of Carbon Credits was less than a dollar.

Figure 1

Fixed CER Prices declared at MDL projects*

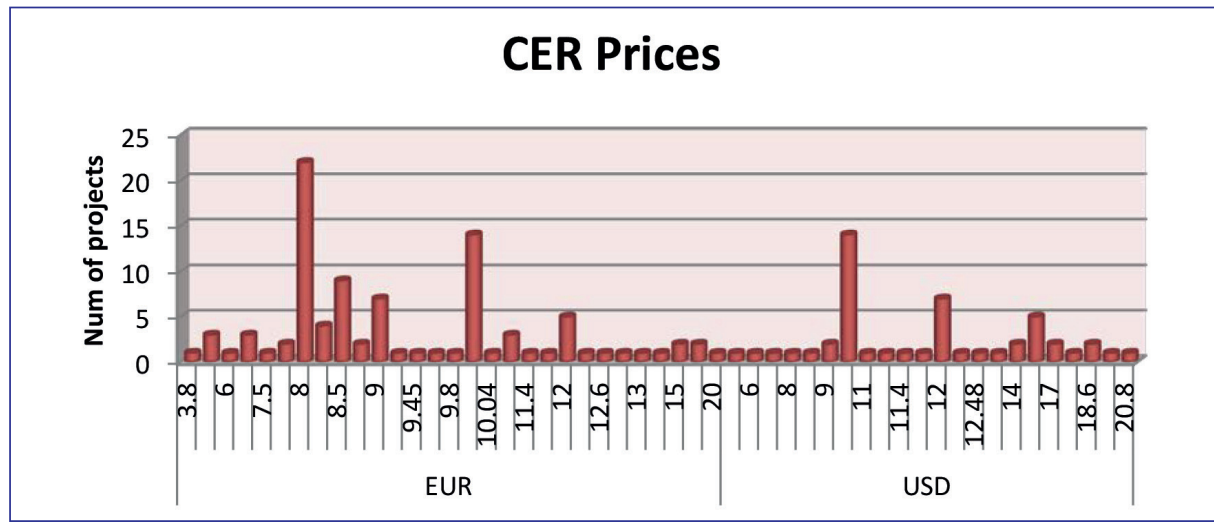

*few MYR, RMB, VND and INR occurrences translated or ignored Source: Bufoni (2015).

The analyses of others revenues sources like gate fee, energy tariffs, and property taxation are not enough to competitively support the project's economic attractiveness. The declared reason is the "lack of clear policy, regulation, and direction associated with subsidies on fossil fuel, but not (or not adequate) in renewable energy case" (3686). In some cases, the electricity prices were subsidized approximately $15 \%$ to $55 \%$ in Colombia $(35 €)(3332,5402)$, and tariffs were 22 times lower (3.30€) than production costs in Cuba (2260). Despite the uncertainties related to operational expenses (OPEX), the revenues in time are estimated constant for the entire operation period.

Figure 2

\section{Benchmark Average of Host Countries}

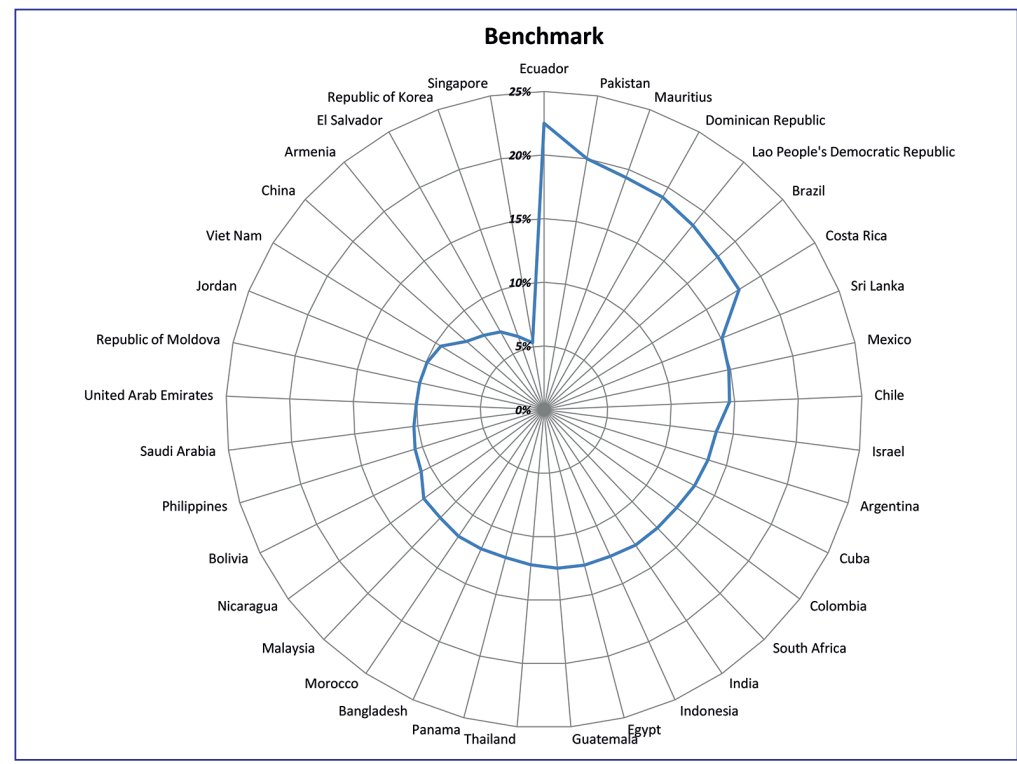

Source: Elaborated by the authors. 
A benchmark indicator tests the attractiveness itself. This reference should be utilized as the discount rate in net present value calculations, or compared to the project's internal rate of return. The manual recommends that benchmarks shall be derived from (1) the CAPM with the adequate risk premium above "risk-free" bond rates; (2) lending rates that reflect the comparable project activity cost of financing; (3) WACC of the company under similar conditions; (4) an official government or approved benchmark; and (5) if any of the above is not applicable, other indicators are used.

Despite the recommendation, some projects use the flat government bond rates as benchmarks which are inadequate (2751, $3042,3464,3958,6039,6699$ and 7637). The CAPM is the often benchmark, adjusted by average energy or waste market risks, or when a bank heavily finances, by lending rates (8851). The full analysis on WACC is complex because of before reference needs and rarely used $(2970,3643)$. Reference to official government benchmarks are $15 \%$ from Israel $(3820,6252,7777$ and 8980$)$ and $8 \%$ in China (3716, 3837, 5326 and 5828). Other references include credit rating agencies, such as Fitch Ratings, Moody's, Standard \& Poor's (e.g., 8603) and the International Monetary Fund (IMF), and the World Bank expected return, shown in the "Guidelines on the assessment of investment analysis" (UNFCCC, 2015a). Figure 2 depicts the average benchmark declared by each country.

Moreover, designers do not always use the benchmark as the interest rate $(i)$, to calculate the NPV. Sometimes they use a higher rate $(941,1301$ and 4291), and often a lower rate $(1240,1242,1307,1355,1435,1626,2028,2271$ and 2467). All PDDs justify this behavior on the fact that the rate is more conservative, which is a controversial concept because the lower rate overestimates future positive cash flows.

\section{DISCUSSION}

The results indicate that engineers and technicians of the waste management sector elaborate the project design documents based on their finance knowledge. The spreadsheets appended also suggest that the budgets and forecast are not in compliance with most accounting standards. Furthermore, financial assumptions do not meet the main IASB concepts described at the framework for the preparation and presentation of financial statements, which the objective is "to provide information useful to financial statement users in making economic decisions" including estimates of the future (BARTH, 2006, p. 272). The values are intentionally "stressed."

On the other hand, UNFCCC manuals, standards, and guidelines do not foster the use of the project's repository as a data source to built economic indicators and statistics (UNFCCC, 2009, 2011, 2012, 2015d). Because the lack of comparability, trustworthiness, and understandability, the usefulness of the statements as a predictive and feedback tools are low. We shall remember that UNFCCC is a Convention under the same United Nations Agency that held the Working Group of Experts on International Standards of Accounting and Reporting (ISAR, 2016)intergovernmental consensus building, information dissemination and technical cooperation. ISAR has a number of areas of work, including: IFRS implementation, accounting by SMEs, professional qualification requirements of accountants, corporate governance disclosure, corporate responsibility reporting, environmental reporting and Accounting Development Tool (ADT.

The project's Validation Report at UNFCCC/CDM website (UNFCCC, 2015b) amends the original document but reexamines the financial parameters individually. However, no PDD's adjusted financial statement is available, and no periodic consolidated statement is accessible. Because the modification presents this information separately and only about project's inception, just with a significant research effort, anyone will poorly infer how the project is performing.

However, studying carbon management accounting Ascui (2014) finds that the informational gap in projects management accounting is more an opportunity to collaborate with practitioners than a problem. The results reinforce the managerial approach of sustainability accounting need which "provides tools to measure and manage areas outside the traditional financial accounting and assist decision-making by internal and external stakeholders." The results contradict the literature's critical approach to sustainable accounting and reporting about how its utility is at odds with the corporations in a capitalist market system (YOUNG, 2011, p. 168).

Furthermore, according to Cho and Giordano-Spring $(2015$, p. 2), the "number of accounting researchers and practitioners who realize that the conventional theory and practice is ill-suited to the challenges of the modern environment" grows. Along with the general (and paradigmatic) theoretical model proposals for organizations and accountants new environmental accounting systems (JONES, 2010), the analysis shows a large room for accounting research and services at environmental projects financial and feasibility studies. The CDM reports formatting and an organized database would greatly help. 


\section{CONCLUSIONS}

This paper aims to investigate the financial assumptions and disclosure quality at 432 projects design documents of the waste management sector (13) under UNFCCC's Clean Development Mechanism as a Kyoto Protocol instrument.

The results show that the IPCCC has no reporting model, standard or template to present the projects financial information. The CDM guidelines refer to the 'local accounting regulations where available or international best practice,' but some financial assumptions clear indicate result reporting administration and bias.

Because all these issues, many desired qualitative characteristics of financial information are not adequate. Briefly, the information is poor, so the assessment utility is low. In authors' opinion, the IPCCC lost the opportunity to assess a significant financial database to aid the environmental projects initiatives prospection, research, feasibility, and continuity.

The results suggest that, if following financial standards and accounting reporting guidelines, many projects now registered would not. The CERs revenue is overestimated to meet the barrier alleviation rule. The same happens to the expenditures inflation and other income estimates, inadequate exchange and discount rates use, just to cite some problems.

The conclusion is that except for rare cases, it is not possible to know how these projects are performing, and which impact the carbon prices drop will have on the project's feasibility. However, if the presented information was and would be intended to support investment decisions, we foresee some flaws and pitfalls that will add more risk to systemic one, demanding higher expected rates of return to be attractive. Thus, we conclude that reporting quality is a relevant feasibility barrier for CDM projects.

In accounting research concern, the study conclusions support the trend that the managerial approach of social and environmental accounting (SEA) are demanded and has ample room for development. Future research on economic and financial disclosure quality, statement format, and in consequence, the feasibility of environmental projects like CDMs are wanted. 


\section{REFERENCES}

ALLESCH, A.; BRUNNER, P. H. Assessment methods for solid waste management: A literature review. Waste Management \& Research, v. 32, n. 6, p. 461-473, 2014.

ASCUI, F. A Review of Carbon Accounting in the Social and Environmental Accounting Literature: What Can it Contribute to the Debate?. Social and Environmental Accountability Journal, v. 34, n. 1, p. 6-28, 2014.

BARTH, M. E. Including Estimates of the Future in Today's Financial Statements. Accounting Horizons, v. 20, n. 3, p. 271-285, 2006.

BARTL, A. Barriers towards achieving a zero waste society. Waste Management, v. 31, n. 12, p. 2369-2370, 2011.

BARTL, A. Moving from recycling to waste prevention: A review of barriers and enables. Waste Management \& Research, v. 32, n. 9, p. 3-18, 2014.

BOWEN, G. A. Document Analysis as a Qualitative Research Method. Qualitative Research Journal, v. 9, n. 2, p. 27-40, 2009.

BUFONI, A. L.; OLIVEIRA, L. B.; ROSA, L. P. The declared barriers of the large developing countries waste management projects: The STAR model. Waste Management, v. 52, p. 326-338, June 2006

BUFONI, A. L.; OLIVEIRA, L. B.; ROSA, L. P. The financial attractiveness assessment of large waste management projects registered as clean development mechanism. Waste Management, v. 43, p. 497-508, Sept. 2015.

CHO, C. H.; GIORDANO-SPRING, S. Critical perspectives on social and environmental accounting. Critical Perspectives on Accounting, v. 33, p. 1-4, Dec. 2015.

$\mathrm{CHO}, \mathrm{J}$. Validity in qualitative research revisited. Qualitative Research, v. 6, n. 3, p. 319-340, 2006.

CHOWDHURY, M. F. Coding, sorting and sifting of qualitative data analysis: debates and discussion. Quality \& Quantity, v. 49, n. 3, p. 1135-1143, 2014.

COP 10. BC-10/2: Strategic framework for the implementation of the Basel Convention for 2012-2021. 2011. Available at: <http:// www.basel.int/Implementation/StrategicFramework/Decisions/ tabid/3808/Default.aspx>. Accessed on: 22 June 2018.

DAVIDSON, J.; JACOBS, C. The Implications of Qualitative - Research Software for Doctoral Work Considering the Individual and Institutional Context. Qualitative Research Journal, v. 8, n. 2, p. 73-80, 2008.

DÖÖS, M.; WILHELMSON, L. Proximity and distance: phases of intersubjective qualitative data analysis in a research team. Quality \& Quantity, v. 48, n. 2, p. 1089-1106, 2012.

EGBERG THYME, K. et al. Qualitative content analysis in art psychotherapy research: Concepts, procedures, and measures to reveal the latent meaning in pictures and the words attached to the pictures. The Arts in Psychotherapy, v. 40, n. 1, p. 101-107, 2013.

EUROPEAN COMMISSION. The EU Emissions Trading System (EU ETS) - European Commission. 2015. Available at: <http://ec.europa. eu/clima/policies/ets/index_en.htm>. Accessed on: 12 Dec. 2015.

EUROPEAN ENVIRONMENT AGENCY. Managing municipal solid waste - a review of achievements in 32 European counties. EEA Report, n. 2, 2013. Available at: <https://www.eea.europa.eu/publications/ managing-municipal-solid-waste>. Accessed on: 22 June 2018.

GODFREY, L.; SCOTT, D.; TROIS, C. Caught between the global economy and local bureaucracy: the barriers to good waste management practice in South Africa. Waste Management \& Research, v. 31, n. 3, p. 295-305, 2013.

GUERRERO, L. A.; MAAS, G.; HOGLAND, W. Solid waste management challenges for cities in developing countries. Waste Management, v. 33, n. 1, p. 220-232, 2013.

HOORNWEG, D.; BHADA-TATA, P. What a Waste: A Global Review of Solid Waste Management. 2012. Available at: <https://openknowledge. worldbank.org/handle/10986/17388>. Accessed on: 22 June 2018.

INANC, B. et al. Development of a database of landfills and dump sites in Asian countries. Journal of Material Cycles and Waste Management, v. 6, n. 2, p. 97-103, 2004.

ISAR. ISAR Corporate Transparency Accounting. 2016. Available at: <http://unctad.org/en/Pages/DIAE/ISAR/ISAR-Corporate-TransparencyAccounting.aspx>. Accessed on: 16 June 2016.

JONES, M. J. Accounting for the environment: Towards a theoretical perspective for environmental accounting and reporting. Accounting Forum, v. 34, n. 2, p. 123-138, 2010.

KRIPPENDORFF, K. Measuring the Reliability of Qualitative Text Analysis Data. Quality \& Quantity, v. 38, n. 6, p. 787-800, 2004.

MACKENSEN, K.; WILLE, U. No Title. Quality and Quantity, v. 33, n. 2, p. 135-156, 1999.

OECD. Municipal waste. 2015. Available at: <https://data.oecd.org/ waste/municipal-waste.htm>. Accessed on: 22 June 2018.

POINT CARBON. Point Carbon, 2012. Carry-over of AAUS from CP1 to CP2 - Future Implications for the Climate Regime. Point Carbon. 2012. Available at: <http://carbonmarketwatch.org/wp-content/ uploads/2012/11/AAU-banking-briefing-paper-Point-Carbon.pdf>. Accessed on: 12 Dec. 2015.

SIMÕES, P.; MARQUES, R. C. Influence of regulation on the productivity of waste utilities. What can we learn with the Portuguese experience? Waste Management, v. 32, n. 6, p. 1266-1275, 2012.

SINGH, J. et al. Progress and challenges to the global waste management system. Waste Management \& Research, v. 32, n. 9, p. 800-812, 2014.

SMYTH, R. Exploring Congruence between Habermasian Philosophy, Mixed-Method Research, and Managing Data Using NVivo. International Journal of Qualitative Methods, v. 5, n. 2, p. 131-145, 2006. Available at: <https://ejournals.library.ualberta.ca/index.php/IJQM/article/ view/4395>. Accessed on: 22 June 2018.

TALBOT, D.; BOIRAL, O. Accounting for greenhouse gas emissions: a counter-account of sustainability reports. In: CSEAR SOUTH AMERICA, 2015, Salvador. Proceedings... Salvador: Universidade Federal da Bahia, 2015. Available at: <http://csearsouthamerica.net/events/ files/conferences/1/schedConfs/4/papers/104/public/104-641-3-PB. pdf $>$. Accessed on: 22 June 2018. 
UNFCCC. Guidelines for objective demonstration and assessment of barriers. 2009. Available at: <https://cdm.unfccc.int/EB/050/ eb50_repan13.pdf>. Accessed on: 4 July 2015.

UNFCCC. CDM-Executive Board Annex 5: guidelines on the assessment of investment analysis. 2011. Available at: <https://cdm.unfccc.int/ sunsetcms/storage/contents/stored-file-20150817153801600/Reg_ guid03.pdf>. Accessed on: 22 June 2018.

UNFCCC. Methodological tool Combined tool to identify the baseline scenario and demonstrate additionality. 2012. Available at: <http:// cdm.unfccc.int/methodologies/PAmethodologies/tools/am-tool-02v5.0.0.pdf>. Accessed on: 04 July 2015.

UNFCCC. CDM-EB65-A05-STAN. Standard, CDM Project Standard. 2015a. Available at: <https://cdm.unfccc.int/sunsetcms/storage/ contents/stored-file-20150225165159970/reg_stan01.pdf>. Accessed on: 22 June 2018.

UNFCCC. CDM: About CDM. 2015b. Available at: <https://cdm.unfccc. int/about/index.html>. Accessed on: 12 Dec. 2015.

UNFCCC. CDM Project Search. 2015c. Available at: <https://cdm. unfccc.int/Projects/projsearch.html>. Accessed on: 18 Dec. 2015.

UNFCCC. Kyoto Protocol. 2015d. Available at: <http://unfccc.int/ kyoto_protocol/items/2830.php>. Accessed on: 12 Dec. 2015.
USEPA. Municipal Solid Waste Generation, Recycling, and Disposal in the United States: Facts and Figures for 2012. 2014. Available at: <http://www3.epa.gov/epawaste/nonhaz/municipal/pubs/2012_ msw_fs.pdf $>$. Accessed on: 22 June 2018.

UNITED NATIONS ENVIRONMENT PROGRAMME (UNEP). Global Waste Management Outlook (GWMO). 2015. Available at: <http:// unep.org/ietc/Portals/136/Publications/Waste Management/GWMO report/GWMO_report.pdf>. Accessed on: 22 June 2016.

WILSON, D. C.; VELIS, C. A. Waste management - still a global challenge in the 21st century: An evidence-based call for action Waste Management \& Research, v. 33, n. 12, p. 1049-1051, 2015.

YIN, R. K. Case Study Research: Design and Methods. Thousand Oaks: SAGE, 2013. Available at: <https://books.google.com/ books?id=OgyqBAAAQBAJ\&pgis=>. Accessed on: 22 June 2018.

YOON, J.-H.; SIM, K. Why is South Korea's renewable energy policy failing? A qualitative evaluation. Energy Policy, v. 86, p. 369-379, Nov. 2015.

YOUNG, A. Sustainability Accounting and Reporting: Fad or Trend?. Social and Environmental Accountability Journal, v. 31, n. 2, p. 168-169, 2011.

André Luiz Bufoni

Universidade Federal do Rio de Janeiro, Rio de Janeiro - RJ, Brazil. E-mail: bufoni@facc.ufrj.br

Aracéli Cristina de Sousa Ferreira

Universidade Federal do Rio de Janeiro, Rio de Janeiro-RJ, Brazil. E-mail: araceli@facc.ufrj.br

Luciano Basto Oliveira

Universidade Federal do Rio de Janeiro, Rio de Janeiro - RJ, Brazil. E-mail: Iuciano@ivig.coppe.ufrj.br 


\section{APPENDIX A}

Table A.1

Projects host, reductions, and type +2 countries

\begin{tabular}{|c|c|c|c|c|c|c|c|c|}
\hline Hosts & 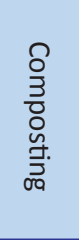 & 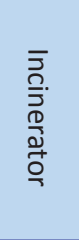 & 悀 & 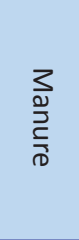 & $\begin{array}{l}\text { 刃 } \\
\text { 뀨 }\end{array}$ & 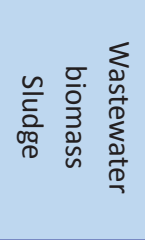 & $\begin{array}{l}\overrightarrow{0} \\
\underline{\underline{D}}\end{array}$ & 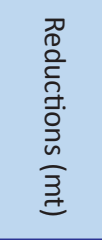 \\
\hline China & 1 & 37 & 46 & 4 & & 6 & 94 & 13.14 \\
\hline Brazil & & 1 & 49 & 20 & & & 70 & 13.56 \\
\hline Mexico & & & 29 & 22 & & & 51 & 4.79 \\
\hline Thailand & & & 5 & & & 18 & 23 & 2.30 \\
\hline Indonesia & 5 & & 9 & 1 & & 6 & 21 & 2.14 \\
\hline Chile & & & 15 & 5 & & & 20 & 2.52 \\
\hline Malaysia & 1 & & 8 & & & 10 & 19 & 1.69 \\
\hline Colombia & 2 & & 11 & & & 1 & 14 & 3.30 \\
\hline Vietnam & 2 & & 5 & 1 & & 4 & 12 & 1.92 \\
\hline India & 3 & & 3 & 1 & 3 & 1 & 11 & 1.25 \\
\hline Israel & & & 9 & 2 & & & 11 & 1.14 \\
\hline Argentina & & & 9 & & & & 9 & 3.26 \\
\hline South Africa & & & 6 & & & 1 & 7 & 1.67 \\
\hline Philippines & 1 & & 4 & & & 1 & 6 & 1.14 \\
\hline Ecuador & & & 2 & 3 & & & 5 & 0.32 \\
\hline Peru & & & 3 & & & & 3 & 0.43 \\
\hline Guatemala & & & 1 & & & 1 & 2 & 0.24 \\
\hline United Arab Emirates & & & 2 & & & & 2 & 0.31 \\
\hline Costa Rica & & & 2 & & & & 2 & 0.19 \\
\hline Azerbaijan & & 1 & 1 & & & & 2 & 0.15 \\
\hline Egypt & 1 & & 1 & & & & 2 & 0.40 \\
\hline Pakistan & 1 & & 1 & & & & 2 & 0.21 \\
\hline Cameroon & & & 2 & & & & 2 & 0.19 \\
\hline The Republic of Korea & & & 2 & & & & 2 & 1.62 \\
\hline Jordan & & & 2 & & & & 2 & 0.25 \\
\hline Saudi Arabia & & & 2 & & & & 2 & 0.49 \\
\hline Bangladesh & 1 & & 1 & & & & 2 & 0.17 \\
\hline The Syrian Arab Republic & & & 2 & & & & 2 & 0.13 \\
\hline Armenia & & & 1 & 1 & & & 2 & 0.20 \\
\hline Tunisia & & & 2 & & & & 2 & 0.69 \\
\hline Morocco & & & 1 & & & 1 & 2 & 0.18 \\
\hline Côte d’Ivoire & & & 2 & & & & 2 & 0.59 \\
\hline Nicaragua & & & & & & 2 & 2 & 0.21 \\
\hline Nigeria & 1 & & 1 & & & & 2 & 0.41 \\
\hline Less than 2 & 1 & & 14 & & & 4 & 19 & 2.28 \\
\hline TOTAL & 20 & 39 & 252 & 60 & 3 & 56 & $431^{*}$ & 63.48 \\
\hline Reductions & 1.72 & 4.89 & 46.34 & 4.72 & 0.28 & 5.46 & 63.48 & $63.61 *$ \\
\hline
\end{tabular}

*+1 Sri Lanka gasification project (0.13Mt reductions)

Source: Elaborated by the authors, based on UNFCCC (2014). 